\title{
Two new species of Leporinus Agassiz (Characiformes: Anostomidae) from eastern basins of Brazil, and redescription of $L$. melanopleura Günther
}

\author{
José L. O. Birindelli ${ }^{1,2}$, Heraldo A. Britski ${ }^{1}$ and Julio C. Garavello ${ }^{3}$
}

Two new species of Leporinus are described from coastal rivers of southern Bahia, Brazil. One of the new species has a bright red blotch immediately dorsal to the pectoral-fin origin in life, three dark blotches along the lateral line that distinctly increase in size posteriorly, and dark longitudinal lines between scale rows on the side of body. The second new species possesses a single broad dark midlateral stripe, encompassing one or two scale rows of depth on the body and centered on the scale row below the lateral line, a dark adipose fin, and a conspicuous dark blotch on the caudal peduncle. The first new species is known only from the rio de Contas and the second from the rio das Almas and rio Jiquiriçá. In addition, Leporinus melanopleura is redescribed based on a designated lectotype and additional specimens collected in the rio Una. Leporinus melanopleura has a single broad dark midlateral stripe, encompassing one or two scale rows of depth on the body, centered on the scale row below lateral line, a hyaline adipose fin (red in life), and an inconspicuous dark blotch on the caudal peduncle.

Duas espécies novas de Leporinus são descritas com base em exemplares de rios costeiros do sudeste da Bahia, Brasil. Uma das espécies novas possui uma mancha vermelho-viva imediatamente dorsal à origem da nadadeira peitoral em vida, três manchas escuras sobre a linha lateral que aumentam de tamanho para trás, e linhas escuras longitudinais entre as séries de escamas na lateral do corpo. A segunda espécie nova apresenta uma única faixa escura sobre o corpo, com altura de uma ou duas fileiras de escamas e centrada na série de escamas da linha lateral, nadadeira adiposa escura, e uma conspícua mancha escura sobre o pedúnculo caudal. A primeira espécie nova é conhecida somente do rio de Contas e a segunda dos rios das Almas e Jiquiriçá. Além disso, Leporinus melanopleura é redescrita com base no lectótipo, designado no presente trabalho, e outros exemplares coletados no rio Una. Leporinus melanopleura possui uma única faixa escura sobre o corpo, com altura de uma ou duas fileiras de escamas e centrada na série de escamas abaixo à linha lateral, nadadeira adiposa hialina (vermelha em vida), e uma mancha escura inconspícua sobre o pedúnculo caudal.

Key words: Anostomoidea, Leporinus melanostictus, Neotropics, Ostariophysi, Taxonomy.

\section{Introduction}

Leporinus Agassiz is one of the largest genera in the order Characiformes, with approximately 80 valid species (Garavello \& Britski, 2003; Eschmeyer, 2012). Recent collecting trips and increasing analysis of specimens deposited in fish collections have revealed a still great number of undescribed species in the genus (e.g., Birindelli \& Britski, 2009; Feitosa et al., 2011), as well as many taxonomic problems yet to be investigated (e.g., Britski et al., 2011; Britski et al., 2012).

Ongoing taxonomic studies of the species of Leporinus from eastern Brazilian drainages revealed three species with unique color patterns and restricted distributions. The species are respectively known from the rio Una, rio das Almas and rio Jiquiriçá, and rio de Contas, coastal rivers in the state of Bahia, from which only one species of Leporinus, L. bahiensis Steindachner, is recognized (Garavello \& Britski, 2003; Britski $\&$ Garavello, 2007). The preliminary study of the three species indicated that they are distinct from Leporinus bahiensis and, in fact, from all congeners, based on our present knowledge on the taxonomy of Leporinus (e.g., Géry, 1977; Garavello, 1979; Britski et al., 1988). The study of the syntypes of Leporinus melanopleura Günther revealed, however, that the latter include two different species and that two of the syntypes are conspecific with the aforementioned samples from rio Una.

Leporinus melanopleura was described by Günther (1864) based on three specimens, two of them collected by

\footnotetext{
${ }^{1}$ Museu de Zoologia, Universidade de São Paulo, Caixa Postal 42494, 04218-970 São Paulo, SP, Brazil. josebirindelli@yahoo.com (JLOB), heraldo@usp.br (HAB)

${ }^{2}$ Departamento de Biologia Animal e Vegetal, Universidade Estadual de Londrina, Caixa Postal 6001, CEP 86051-980 Londrina, PR, Brazil. ${ }^{3}$ Universidade Federal de São Carlos, Rodovia Washington Luiz, km 235, 676, 13565-905 São Carlos, SP, Brazil. garavello@ufscar.br
} 
Otto Wucherer at an unspecified locality in Bahia, and a third collected by Cumberland in the rio Cipó, a tributary of the rio das Velhas, part of the rio São Francisco basin, in Minas Gerais State. Until now, the name L. melanopleura has appeared only in fish catalogs (Fowler, 1950; Garavello \& Britski, 2003; Britski \& Garavello, 2007), or has been applied to specimens of L. taeniatus Lütken (Travassos, 1940; Petrere, 1989; Teixeira \& Gurgel, 2005; Sampaio \& Sato, 2009), or incorrectly to other species from Colombia and Venezuela (Lasso et al., 2004; Maldonado-Ocampo et al., 2008; Lasso et al., 2009; Gama, 2011).

The aim of the present contribution is to redescribe Leporinus melanopleura based on a designated lectotype and additional specimens recently collected, and to describe two new species of Leporinus from eastern Brazilian drainages.

\section{Material and Methods}

Counts and measurements were taken according to Britski \& Garavello (1978) and Winterbottom (1980). Standard length (SL) is expressed in mm and all other measurements are expressed as percentage of SL, except subunits of the head, which are expressed as percentages of head length. Meristic data are given in the description, with the frequency of each count provided in parentheses after the respective count, and an asterisk indicating counts of the holotype (or lectotype). The lateral-line scale count included the pored scales extending onto the base of the median caudal-fin rays; counts of the longitudinal scale rows above lateral line exclude the lateral-line scale and the middorsal scale row; counts of the longitudinal scale rows below lateral line exclude the lateral-line scale row and include half a scale row when the pelvic-fin origin is immediately behind the middle of a scale. Weberian-apparatus vertebrae were counted as four elements and included in the vertebral counts; the compound caudal centrum (preural 1 + ural 1) of the caudal region was counted as a single element. The pattern of radii was defined on scales immediately above the lateral line row at the vertical through the dorsal-fin origin.

All examined specimens are alcohol preserved, except when indicated by CS, clear and stained according to Taylor \& van Dyke (1985), or SK, dry skeleton prepared following generally the methods of Bemis et al. (2004). Institutional abbreviations are: ANSP, Academy of Natural Sciences of Philadelphia, Philadelphia; BMNH, Natural History Museum, London; MCP, Museu de Ciências e Tecnologia da Pontifícia Universidade Católica, Porto Alegre; MZUSP, Museu de Zoologia, Universidade de São Paulo, São Paulo; NMW, Naturhistorisches Museum, Vienna; UFBA, Universidade Federal da Bahia, Salvador; UFPB, Universidade Federal da Paraíba, João Pessoa; UNT, Universidade Federal do Tocantins, Porto Nacional; USNM, National Museum of Natural History, Smithsonian Institution, Washington, D.C.

\section{Results}

\section{Leporinus melanopleura Günther, 1864 Figs 1 and 2}

Leporinus melanopleura Günther, 1864: 310 [in part, lectotype (by present designation) and paralectotype from "Bahia", not paralectotype from rio Cipó; type locality: "Bahia" (herein restricted to an indefinite locality within the rio Una drainage, southern Bahia, Brazil)].- Steindachner, 1876: 110 [citation].- Eigenmann \& Eigenmann, 1891: 51 [catalog].- Eigenmann, 1910: 426 [catalog].- Fowler, 1950: 238 [catalog].- Géry, 1960: 283 [citation].- Géry, 1977: 167 [identification key].- Garavello \& Britski, 2003: 76 [catalog].- Britski \& Garavello, 2007: 25 [catalog].

Diagnosis. Leporinus melanopleura is distinguished from all congeners except $L$. melanopleurodes, by having a single broad dark midlateral stripe on body, encompassing two scale rows of depth and centered on the scale row below lateral line. Leporinus melanopleura is further distinguished from congeners except Leporinus amae Godoy, L. arcus Eigenmann, L. amblyrhynchus Garavello \& Britski, L. bistriatus Britski, L. britskii Feitosa, Santos \& Birindelli, L. melanopleurodes, L. sexstriatus Britski \& Garavello, L. striatus Kner, L. taeniatus, L. taeniofasciatus Britski, L. unitaeniatus Garavello \& Santos, and L. vanzoi Britski \& Garavello, by the presence of a dark midlateral stripe on body. Leporinus melanopleura is additionally distinguished from Leporinus arcus, L. amblyrhynchus, L. britskii, L. sexstriatus, L. striatus, L. taeniatus, L. taeniofasciatus, L. unitaeniatus and $L$. vanzoi, by having three scale rows between dorsal-fin origin and lateral line and three or 3.5 scale rows between lateral line and pelvic-fin origin ( $v s$. four or five). Leporinus melanopleura is distinguished from Leporinus amae and $L$. bistriatus by having a single dark midlateral stripe on body encompassing two scale rows of depth and centered on the scale row below lateral line (vs. a dark midlateral stripe centered on lateral-line scale row, and a second dark stripe on dorsum); and from Leporinus amae by having adipose fin red in life (vs. hyaline). Leporinus melanopleura is distinguished from L. melanopleurodes by having a subinferior mouth (vs. inferior), hyaline (red in life) adipose fin (vs. dark), and an inconspicuous dark blotch on caudal peduncle ( $v s$. conspicuous).

Description. Morphometric data in Table 1. Small size, relative to congeners. Largest examined specimen $104.3 \mathrm{~mm}$ SL. Head and body elongate and moderately compressed. Dorsal profile gently convex from snout tip to dorsal-fin origin, somewhat straight along dorsal-fin base, gently convex or straight from terminus of dorsal-fin base to adipose-fin origin, and distinctly concave from adipose-fin origin to base of anteriormost procurrent ray of caudal fin. Ventral profile straight to slightly concave from lower jaw to vertical through posterior margin of opercle, gently convex from latter point to anal-fin origin, 
somewhat straight along anal-fin base, and concave from terminus of anal-fin base to base of anteriormost procurrent ray of caudal fin. Greatest body depth at dorsal-fin origin.

Mouth subinferior, and longitudinally aligned with ventral margin of infraorbital series, in specimens of $50 \mathrm{~mm}$ SL or longer (Fig. 1a-c). Mouth terminal in specimens of about 30 mm SL (Fig. 1d) and dorsally oriented in specimens of approximately $15 \mathrm{~mm}$ SL (Fig. 1e). Snout rounded, anteriorly blunt. Premaxilla with three incisiform teeth gradually decreasing in size from the symphyseal tooth. Dentary with four incisiform teeth gradually decreasing in size posterolaterally (Fig. 3).
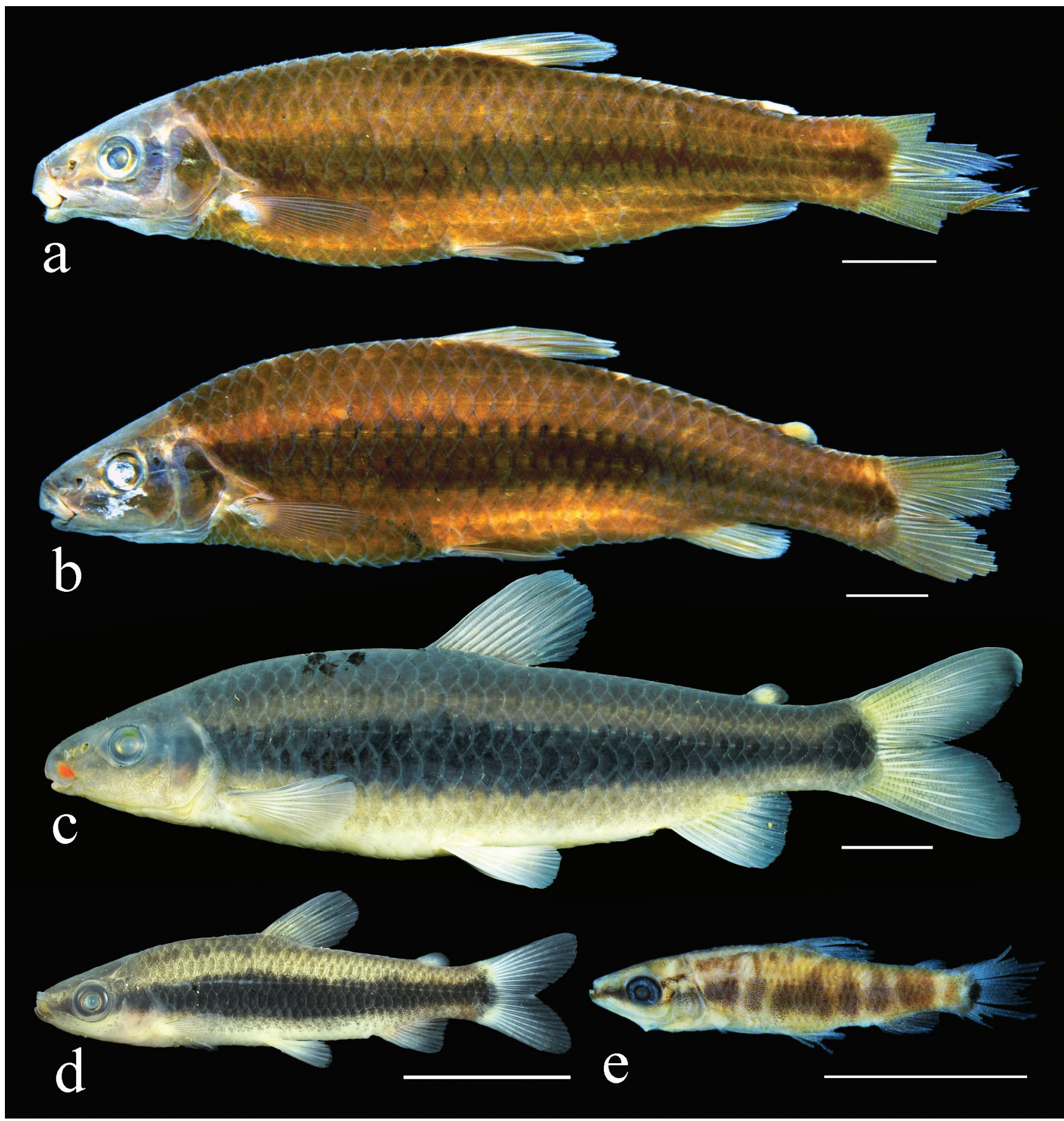

Fig. 1. Leporinus melanopleura: (a) lectotype, BMNH 1863.3.27.6, 91.2 mm SL, "Bahia"; (b) paralectotype, BMNH 1863.3.27.7, 104.3 mm SL, "Bahia"; (c) MZUSP 111246, 90.9 mm SL, rio Una; (d) MZUSP 111246, 27.3 mm SL, rio Una; (e) MCP 17712, 18.4 $\mathrm{mm} \mathrm{SL}$, rio Branco, tributary of rio Una. Scale bars $=10 \mathrm{~mm}$. 
Scales cycloid, with 6 (1), 7 (2), or 8 (2) radii. Lateral line complete, extending from supracleithrum to base of median caudal-fin rays, with 36 (2), 37 (18), or 38* (22) perforated scales. Longitudinal scale rows between dorsal-fin origin and lateral line 3 (42). Longitudinal scale rows between lateral line and pelvic-fin origin 3 (23) or 3.5* (19). Longitudinal scale rows around caudal peduncle 12 (42). Predorsal scales from tip of supraoccipital spine to dorsal-fin origin 10 (2), 11 (21) or $12 *(5)$.

Dorsal-fin rays ii,9 (3) or ii,10* (26). Dorsal-fin origin slightly anterior to midpoint of standard length and to vertical through pelvic-fin origin; distal margin of dorsal fin gently convex. Adipose fin small, teardrop-shaped with origin approximately at vertical through base of last anal-fin ray. Pectoral-fin rays i,13* (8), i,14 (18), i,15 (2), or i,16 (1); tip of adpressed pectoral fin extending to midpoint between origins of pectoral and pelvic fins; distal margin of pelvic fin rounded. Pelvic-fin rays i,8 (29); distal margin of pelvic fin slightly convex. Anal-fin rays ii, 8 (29). Anal-fin origin approximately at vertical through posterior margin of fourth scale anterior to adipose-fin origin; adpressed anal fin not reaching base of caudal-fin rays; distal margin of anal fin straight overall or slightly convex. Principal caudal-fin rays i,8,9,i (29). Caudal fin forked, lobes rounded, upper lobe slightly longer than lower lobe. Vertebrae 36 (4), 37 (1), or $38(3)$.

Color in alcohol. Ground color brown or tan, weakly countershaded. Head and body with conspicuous dark midlateral stripe extending from immediately above posterior nares to end of caudal peduncle. Stripe broad, encompassing two scale rows of depth, and centered on scale row below lateral line, occupying one-half of lateral-line scale row, all of row below it and one-half of adjacent ventral row. Ventral surfaces of head and body pale to cream. Fins generally hyaline, dorsal and caudal fins slightly darkened. Small specimens (up to $20 \mathrm{~mm} \mathrm{SL}$ ) with dark midlateral stripe on head from lower jaw to opercle, dark stripe from posterodorsal portion of eye to supraoccipital spine, eight irregular dark transverse bars forming fragmented midlateral stripe on body, and dark conspicuous spot on base of median caudal-fin rays (Fig. 1e).

Color in life. Life coloration similar to that in preserved specimens with addition of bright red spot on clear area of adipose fin, and red pigmentation on dorsal and distalmost portion of upper lip (Fig. 2).

Distribution. Leporinus melanopleura is apparently endemic of the rio Una, a small coastal river in southern Bahia, Brazil (Fig. 4). The precise collection site of the lectotype of Leporinus melanopleura is unknown; however, because of that species has been collected only in rio Una, that basin is likely the type locality. According to Lima (2001), the Wucherer fishes studied by Günther (1864) apparently originated at localities around Salvador and near the cities of Nazaré, Canavieiras and Ilhéus, in Bahia. The fact that the rio Una is

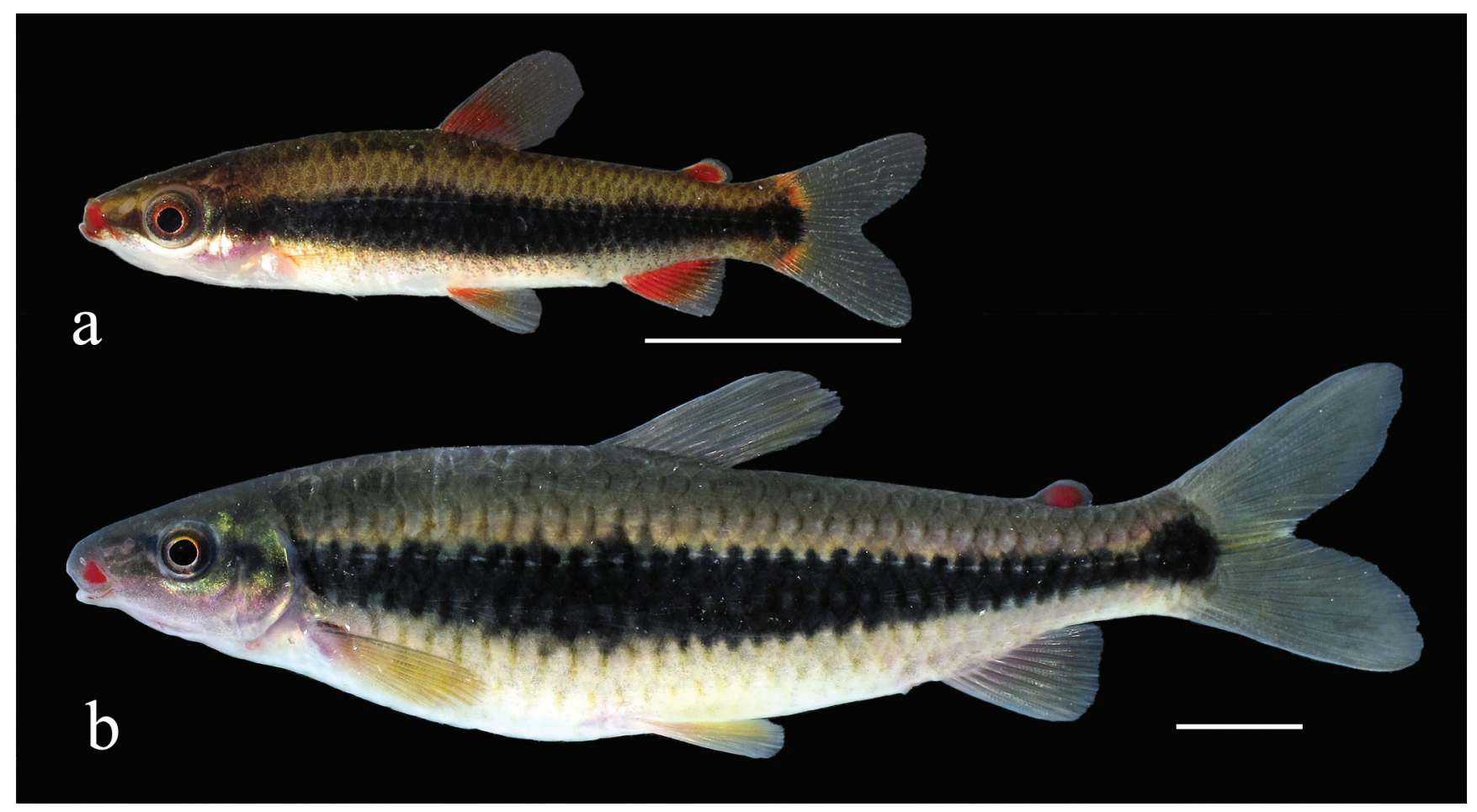

Fig. 2. Leporinus melanopleura: (a) MZUSP 111246, $27.3 \mathrm{~mm}$ SL, rio Una, (b) MZUSP 111246, $90.9 \mathrm{~mm}$ SL, rio Una; both photographed live. Scale bars $=10 \mathrm{~mm}$. 


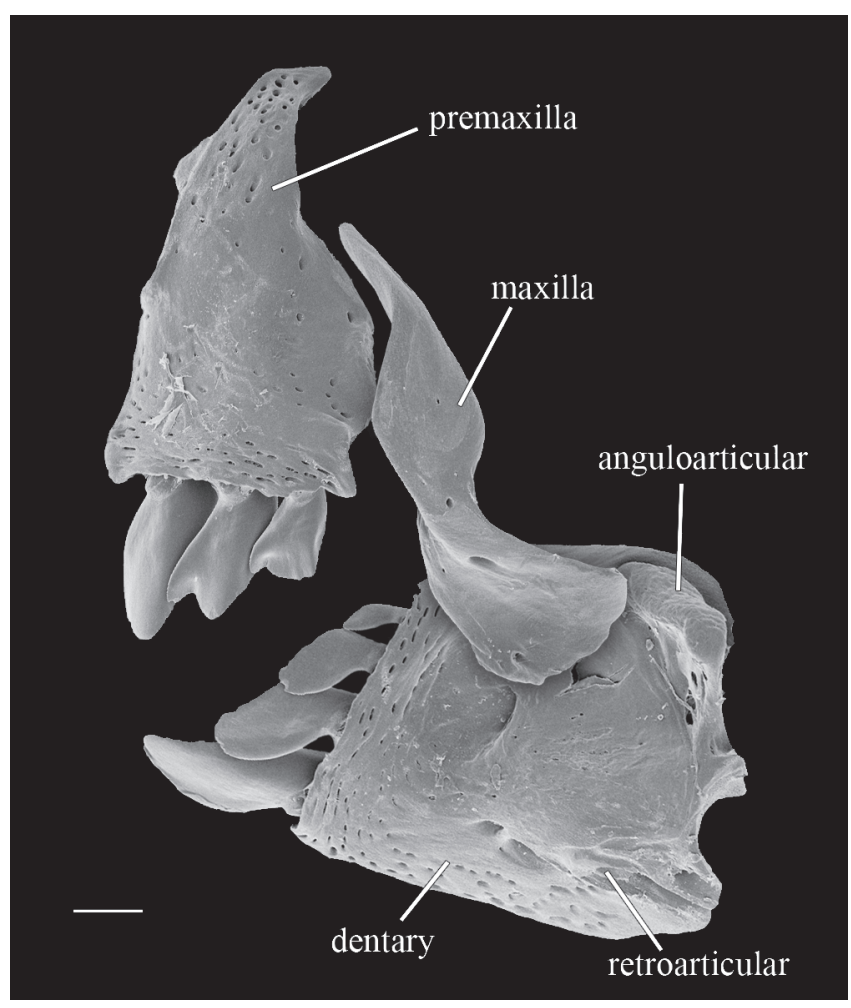

Fig. 3. Scanning electron image of the upper and lower jaws of Leporinus melanopleura in lateral view, MZUSP 100986, $57.6 \mathrm{~mm} \mathrm{SL}$.

located between Ilhéus and Canavieiras, strengthens the probability that the type locality of Leporinus melanopleura is in that basin.

Remarks. Günther (1864) described Leporinus melanopleura based on three specimens, two of them (BMNH 1863.3.27.6-7) collected by Wucherer in "Bahia", and the other (BMNH 1861.5.16.14) collected by Cumberland in the rio Cipó, a tributary of the rio das Velhas, in the rio São Francisco basin, Minas Gerais. We, herein, designate one of the specimens collected in "Bahia" as the lectotype, recognizing this species as possibly endemic to the rio Una, in southern Bahia (Fig. 4). Cumberland's specimen consists only on the left side of a specimen cut along the sagittal plane and preserved as a dry skin glued to a paperboard (Fig. 5a). The specimen collected from rio Cipó does not belong to L. melanopleura since it has 35 lateral-line scales (vs. 36 to 38 in L. melanopleura), four scales between the dorsal-fin origin and the lateral line (vs. three) and four scales between the lateral line and the pelvic-fin origin ( $v S$. three or 3.5), and a dark midlateral stripe centered on the lateralline scale row ( $v s$. a midlateral stripe centered on the scale row below the lateral line). The rio Cipó specimen fits the diagnosis of Leporinus taeniatus (Fig. 5b), a species widely distributed in the rio São Francisco, rio Parnaíba and smaller drainages in northeastern Brazil. Leporinus taeniatus is diagnosed by having a dark midlateral stripe centered on the lateral-line scale

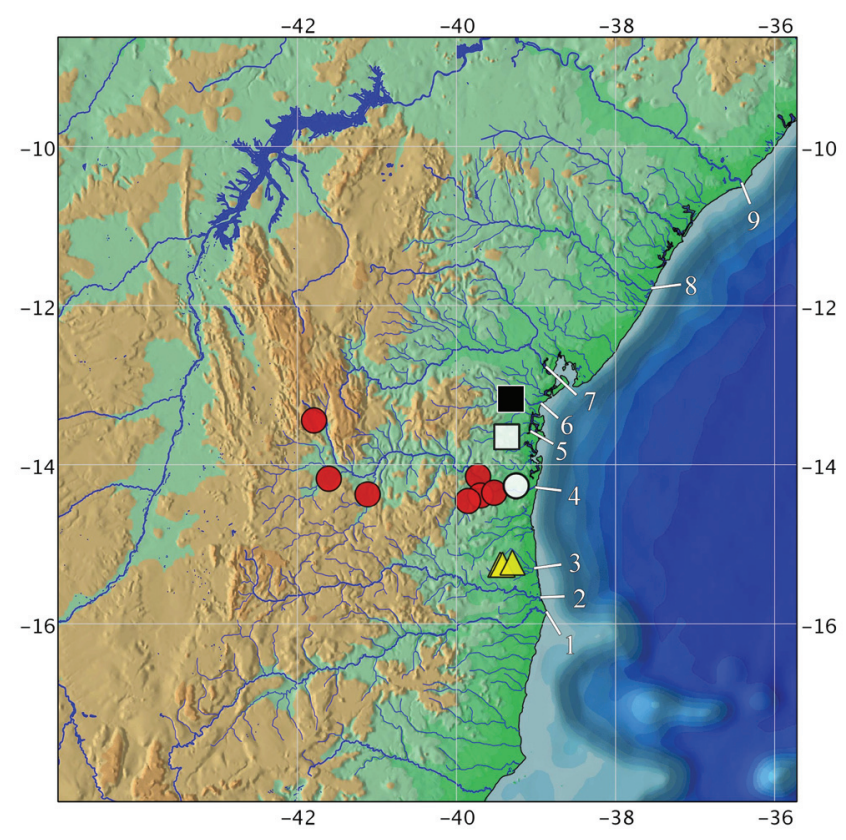

Fig. 4. Distribution of Leporinus melanopleura (triangles), $L$. melanopleurodes (square), and L. brinco (circles); type localities indicates by white symbols. River basins: (1) rio Jequitinhonha, (2) rio Pardo, (3) rio Una, (4) rio de Contas, (5) rio das Almas, (6) rio Jiquiriçá, (7) rio Paraguaçu, (8) rio Itapecuru, and (9) rio São Francisco.

row, dark bars on the dorsum, three teeth on the premaxilla, four on the dentary, 35 to 38 scales in the lateral line and four or five scale rows above and below the lateral line. The only difference between the paralectotype in question and most examined specimens of Leporinus taeniatus is the number of scale rows around caudal peduncle (12 in the paralectotype $v s$. 16). Nevertheless, some specimens of L. taeniatus have 12 irregular scale rows around caudal peduncle, indicating that this feature may vary in L. taeniatus, and that the paralectotype of L. melanopleura from rio Cipó is Leporinus taeniatus.

Various papers report specimens identified as Leporinus melanopleura. Most of those papers are likely citations of Leporinus taeniatus from the rio São Francisco and rivers of northeast Brazil (Fowler, 1941: fig. 88, 1950: fig. 276; Britski et al., 1988; Petrere, 1989), and of $L$. striatus from the río Orinoco basin in Colombia and Venezuela (Lasso et al., 2004; Maldonado-Ocampo et al., 2008; Lasso et al., 2009; Gama, 2011). Although we did not examine all specimens reported on those papers, due to the restricted distribution of Leporinus melanopleura, we judge those citations to be erroneous.

Material Examined. Brazil. ANSP 173829, 6, 29.2-37.0 mm SL; MCP 17712, 1, 18.4 mm SL; MCP 17872, 4, 37.0-54.8 mm SL; MZUSP 100986, 5, 34.5-87.1 mm SL, 1 CS, 57.6 mm SL, Bahia, Camacã, rio Branco, tributary of rio Una, on road BR-101, near São João da Capelinha, $15^{\circ} 15^{\prime} 16^{\prime}$ 'S 39²7'7’W. BMNH 1863.3.27.6 
Table 1. Morphometric data for Leporinus melanopleura $. \mathrm{n}=$ number of specimens; $\mathrm{SD}=$ Standard Deviation.

\begin{tabular}{lccccc}
\hline & $\mathrm{n}$ & Lectotype & Mean & Range & SD \\
\hline Standard Length (mm) & 41 & 91.2 & 66.22 & $18.40-104.30$ & \\
& Percents of Standard Length & & & \\
Predorsal distance & 29 & 49.34 & 48.85 & $46.58-50.54$ & 0.84 \\
Dorsal-fin origin to adipose-fin origin & 20 & - & 84.26 & $80.18-85.96$ & 1.20 \\
Prepelvic distance & 29 & 50.00 & 48.72 & $46.23-52.23$ & 1.30 \\
Body depth & 29 & 24.12 & 23.32 & $20.87-25.43$ & 0.98 \\
Caudal peduncle length & 22 & 14.47 & 15.40 & $14.38-16.37$ & 0.63 \\
Caudal peduncle depth & 29 & 9.54 & 10.08 & $9.40-10.67$ & 0.35 \\
Anal-fin lobe length & 29 & 15.13 & 13.37 & $11.00-15.13$ & 1.16 \\
Head length & 29 & 23.36 & 22.82 & $21.38-24.13$ & 0.77 \\
& Percents of Head Length & & & \\
Preopercle length & 20 & - & 76.53 & $75.14-79.35$ & 1.10 \\
Snout length & 29 & 39.91 & 39.51 & $36.43-42.05$ & 1.51 \\
Head depth & 22 & 71.83 & 75.46 & $71.13-80.23$ & 2.47 \\
Eye diameter & 29 & 22.07 & 24.34 & $20.08-31.30$ & 2.40 \\
Bony interorbital & 29 & 39.91 & 42.32 & $39.47-46.96$ & 1.98 \\
\hline
\end{tabular}

91.2 mm SL, Bahia, lectotype of Leporinus melanopleura Günther, 1864, by present designation. BMNH 1863.3.27.7, 1, $104.3 \mathrm{~mm}$ SL, Bahia, paralectotype of Leporinus melanopleura Günther, 1864. MCP 17708, 1, 85.5 mm SL, Bahia, Arataca, rio Branco, on road between road BR-101 and Una, approximately $3 \mathrm{~km}$ from BR-101, 15¹5'11"S 39²6'37'W. MZUSP 111246, 10, 27.3-90.9 mm SL, Bahia, São José da Vitória, tributary of rio Una, 15² $52.4^{\prime \prime S}$
39²1'10.4'W. MZUSP 111601, 2, 97.5 and $98.6 \mathrm{~mm}$ SL, Bahia, Arataca, rio Aliança, 15¹5'3.6”'S 39²6'36.6”'W. UFBA 4282, 19, 69.0-97.8 mm SL, Bahia, Arataca, rio Aliança, $15^{\circ} 15^{\prime} 28^{\prime \prime} \mathrm{S}$ 39²5'22”W. UFBA 5103, 8, 33.1-69.0 mm SL, Bahia, São José da Vitória, rio Una, at BR-101. UFPB 1695, 22, 31.9-98.8 mm SL; USNM 300676, 8, 47.8-98.2 mm SL, Bahia, Una, ribeirão das Caveiras, tributary of rio Una, $8 \mathrm{~km}$ from São José.

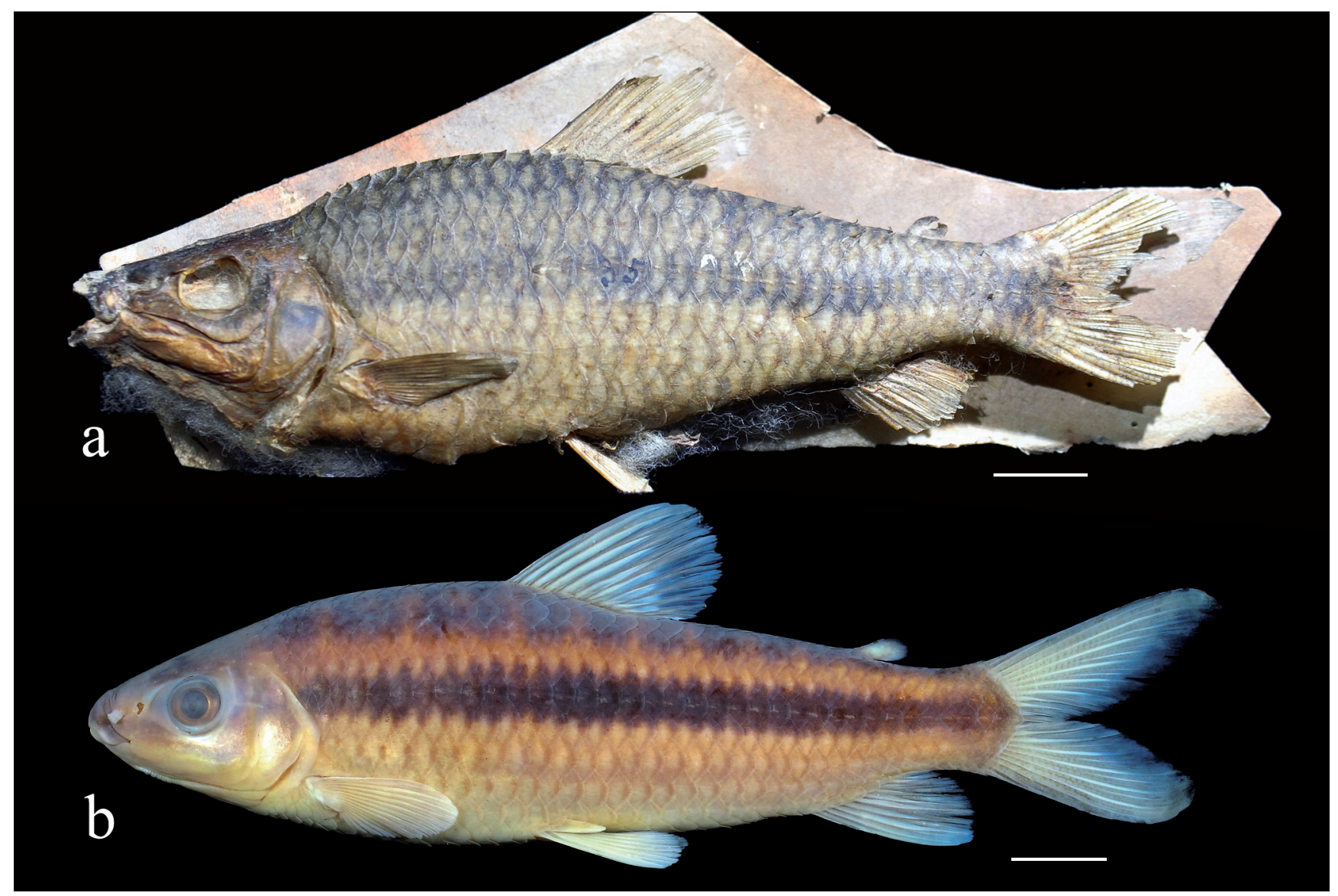

Fig. 5. Leporinus taeniatus: (a) paralectotype of Leporinus melanopleura, BMNH 1861.5.16.14, 102.6 mm SL, rio Cipó, tributary of rio das Velhas, rio São Francisco basin; (b) MZUSP 47459, 96.5 mm SL, rio Verde, tributary of rio São Francisco. Scale bars $=10 \mathrm{~mm}$. 


\section{Leporinus melanopleurodes, new species Figs. 6 and 7}

Holotype. MZUSP 100987, 99.4 mm SL, Brazil, Bahia, Nilo Peçanha, rio das Almas, approximately $10 \mathrm{~km}$ from Nilo Peçanha on road Corredeiras do rio das Almas, $13^{\circ} 36^{\prime} 27.8^{\prime \prime}$ S 39 $9^{\circ} 38.8^{\prime \prime} \mathrm{W}$, 12 Aug 2012, J. L. Birindelli, F. C. Dagosta, and M. V. Loeb.

Paratypes. All from Brazil, Bahia. ANSP 199122, 2, 86.8-95.2 mm SL; MZUSP 111242, 8, 83.3-100.5 mm SL, collected with holotype. MCP 36965, 8, 79.8-128.7 mm SL; MZUSP 109769, 1, 116.7 mm SL, 1 CS, 89.5 mm SL; Laje, rio Jiquiriçá, near road BR-101, 1310'18'S 39¹9'15'W, 14 Oct 2004, J. F. Pezzi da Silva. MZUSP 109764, 6, 85.7-112.9 mm SL, Laje, rio Jiquiriçá, near road BR-101, 1310'18'S 39¹9'15’W, 13 Jul 2011, A. M. Zanata, J. L. Birindelli, P. Camelier, R. Burger \& B. Sardeiro. MZUSP 111227, 3, 88.9113.2 mm SL, Laje, rio Jiquiriçá, near road BR-101, 13¹0'18"S 39¹9'15'W, 11 Aug 2012, J. L. Birindelli, F. C. Dagosta \& M. V. Loeb.

Diagnosis. Leporinus melanopleurodes is distinguished from all congeners, except $L$. melanopleura, by having a single broad dark midlateral stripe on body, encompassing one or two scale rows of depth and centered on the scale row below lateral line. Leporinus melanopleurodes is further distinguished from congeners except Leporinus amae, L. arcus, L. amblyrhynchus, L. bistriatus, L. britskii, L. melanopleura, L. sexstriatus, $L$. striatus, L. taeniatus, L. taeniofasciatus, L. unitaeniatus and $L$. vanzoi, by the presence of a dark midlateral stripe on body. Leporinus melanopleurodes is additionally distinguished from Leporinus arcus, L. amblyrhynchus, L. britskii, L. sexstriatus, L. striatus, L. taeniatus, L. taeniofasciatus, L. unitaeniatus, and $L$. vanzoi, by having three scale rows between dorsal-fin origin and lateral line and three or 3.5 scale rows between lateral line and pelvic-fin origin (vs. four or five). Leporinus melanopleurodes is distinguished from Leporinus amae and L. bistriatus by having a single dark midlateral stripe on body encompassing two scale rows of depth and centered on the scale row below lateral line ( $v s$. a dark midlateral stripe centered on lateral-line scale row, and a second dark stripe on dorsum), a dark blotch on caudal peduncle (vs. absent), and inferior mouth (vs. subinferior). Leporinus melanopleurodes is distinguished from L. melanopleura by having an inferior mouth ( $v s$. subinferior), a dark adipose fin ( $v s$. hyaline, red in life), and a conspicuous dark blotch on caudal peduncle ( $v s$. dark blotch inconspicuous).

Description. Morphometric data in Table 2. Small size, relative to congeners. Largest examined specimen $128.7 \mathrm{~mm}$ SL. Head and body elongate and moderately compressed. Dorsal profile of head and body gently convex from snout tip to dorsal-fin origin, somewhat straight along dorsal-fin base, straight from terminus of dorsal-fin base to adipose-fin origin, and distinctly concave from adipose-fin origin to base of anteriormost procurrent ray of caudal fin. Ventral profile of head and body straight to slightly concave from lower jaw to vertical through posterior margin of opercle, gently convex from latter point to pelvic-fin origin, straight from pelvic-fin origin to anal-fin origin, somewhat straight along anal-fin base, and concave from terminus of anal-fin base to base of anteriormost procurrent ray of caudal fin. Greatest body depth at dorsal-fin origin.

Mouth inferior in all examined specimens (smaller specimen examined $79.8 \mathrm{~mm} \mathrm{SL}$ ), and longitudinally aligned with or slightly ventral to ventral margin of opercle. Snout rounded in lateral view, anteriorly blunt or slightly acute. Premaxilla with three incisiform teeth gradually decreasing in size from symphyseal tooth pair. Dentary with four incisiform teeth gradually decreasing in size posterolaterally (Fig. 8).

Scales cycloid, with 8 (1), 9 (1), or 10 (1) radii. Lateral line complete with 36 (2), 37* (17), or 38 (2) perforated scales, extending from supracleithrum to base of median caudal-fin rays. Longitudinal scale rows between dorsal-fin origin and lateral line 3 (20). Longitudinal scale rows between lateral line and pelvic-fin origin $3 *(15)$ or 3.5 (5). Longitudinal scale rows around caudal peduncle 12 (20). Predorsal scales from tip of supraoccipital spine to dorsal-fin origin 10 (13) or $11 *(7)$.

Dorsal-fin rays ii,10 (20). Dorsal-fin origin slightly anterior to middle of standard length and to vertical through pelvicfin origin; distal margin of dorsal fin rounded. Adipose fin small, teardrop-shaped with origin approximately at vertical through base of last anal-fin ray. Pectoral-fin rays i,13* (4), i,14 (13), or i,15 (3). Tip of pectoral fin almost extending to midpoint between origins of pectoral and pelvic fins; distal margin rounded. Pelvic-fin rays i,8 (20); distal margin of pelvic fin slightly convex. Anal-fin rays ii,8 (20); origin of anal fin approximately at vertical through posterior margin of fourth scale anterior to adipose-fin origin, rear of adpressed fin not reaching base of caudal-fin rays. Distal margin of anal fin approximately straight to slightly convex. Principal caudalfin rays i,8,9,i (20). Caudal fin forked, lobes rounded, upper lobe slightly longer than lower lobe. Vertebrae 37 (5) or 38 (1).

Color in alcohol. Ground coloration of head and body brown or tan; weakly countershaded. Body with conspicuous dark midlateral stripe extending from immediately above posterior nares to end of caudal peduncle, and conspicuous dark oval blotch at posterior of caudal peduncle, encompassing approximately four scale rows of length and two of depth. Stripe broad, encompassing one to two scale rows of depth, and centered on scale row below lateral line, occupying one-half of lateral-line scale row, all of row below it and, sometimes, one-half of adjacent ventral row. Dark midlateral stripe particularly conspicuous in smaller specimens (up to $85 \mathrm{~mm} \mathrm{SL}$ ), and somewhat faded in larger individuals (100 $\mathrm{mm}$ SL or more). Ventral surfaces of head and belly pale to cream. Fins generally dusky, pelvic fin somewhat hyaline. Dark blotch on caudal peduncle, alternatively, somewhat inconspicuous in smaller specimens (up to $85 \mathrm{~mm} \mathrm{SL}$ ) but very conspicuous in larger individuals (100 $\mathrm{mm}$ SL or more).

Color in life. Life coloration similar to that described for preserved specimens, except for bright yellow fins (Fig. 7), and dusky red spot on dorsal and distalmost portion of upper lip. 
Distribution. Leporinus melanopleurodes is known from the rio das Almas and rio Jiquiriçá, two small coastal river in southern Bahia, Brazil (Fig. 4). All examined specimens were collected in fast flowing rapids with clear water over a rocky bottom densely covered with Podostemaceae (Fig. 9).

Etymology. The species name melanopleurodes is from melanopleura, in reference to Leporinus melanopleura, plus the suffix odes, meaning similar to, in allusion to the similarity between this new species and L. melanopleura. An adjective.

\section{Leporinus brinco, new species}

Figs. 10 and 11

Holotype. MZUSP 105166, 128.5 mm SL, Brazil, Bahia, Itajibá, rio Gongogi, tributary of rio de Contas, $14^{\circ} 21$ ' $16.5^{\prime \prime} \mathrm{S} 39^{\circ} 46^{\prime} 23.9^{\prime \prime} \mathrm{W}$, 13 Aug 2012, J. L. Birindelli, F. C. Dagosta \& M. V. Loeb.

Paratypes. All from Brazil, Bahia, rio de Contas basin. ANSP 199123, 2, 144.9-154.0 mm SL; MZUSP 110617, 2, 134.2-173.8 mm SL, $1 \mathrm{SK}, 139.0$ mm SL; UFBA 4843, 12, 132.9-187.2 mm SL, Ipiaú, rio de Contas, approximately $14^{\circ} 9^{\prime}$ S $39^{\circ} 44^{\prime} \mathrm{W}, 27$ Jan

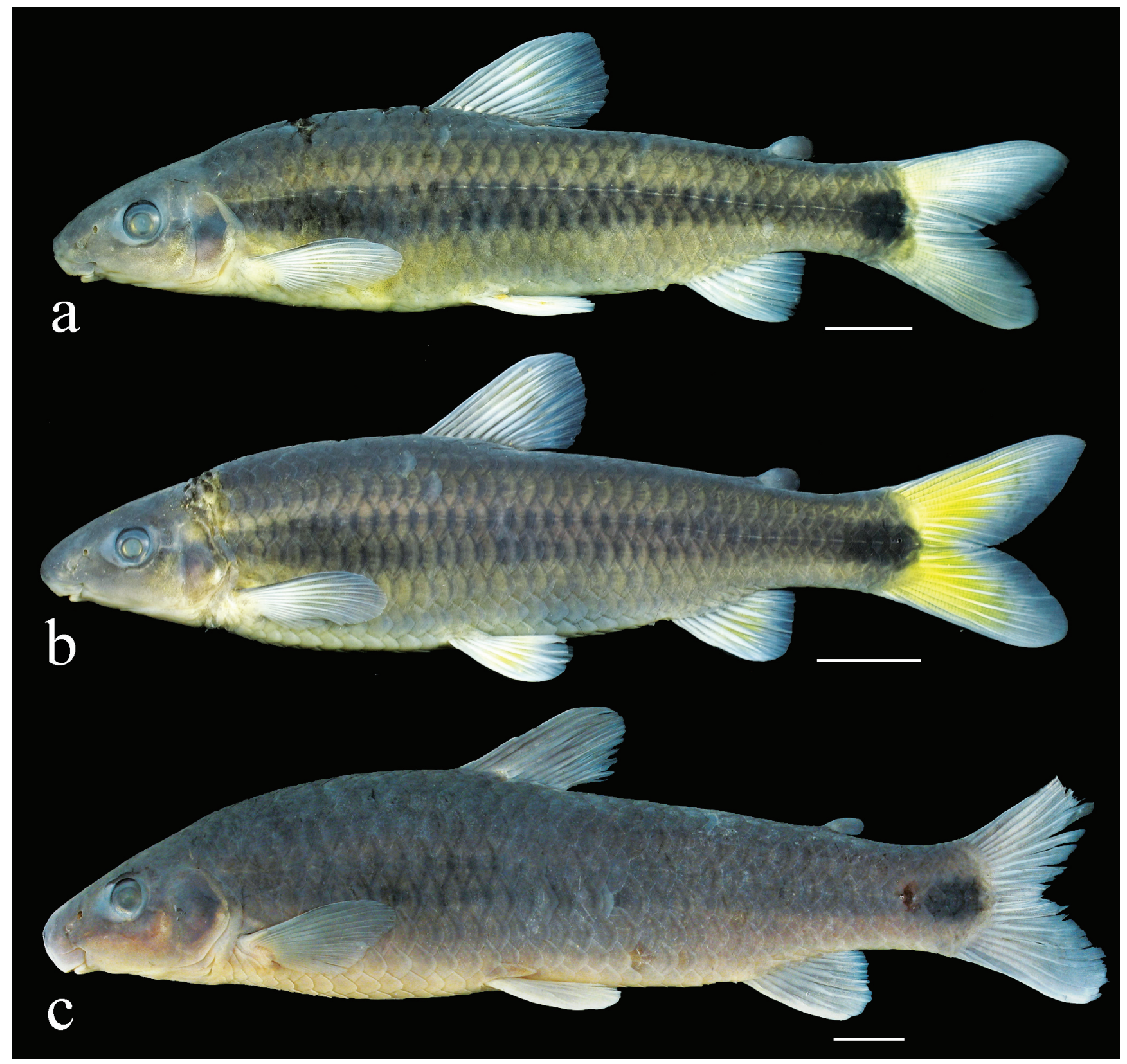

Fig. 6. Leporinus melanopleurodes: (a) holotype, MZUSP 100987, 99.4 mm SL, rio das Almas; (b) paratype, MZUSP 111242, 83.3 mm SL, rio Jiquiriçá; (c) paratype, MCP 36965, 128.7 mm SL, rio Jiquiriçá. Scale bars = $10 \mathrm{~mm}$. 


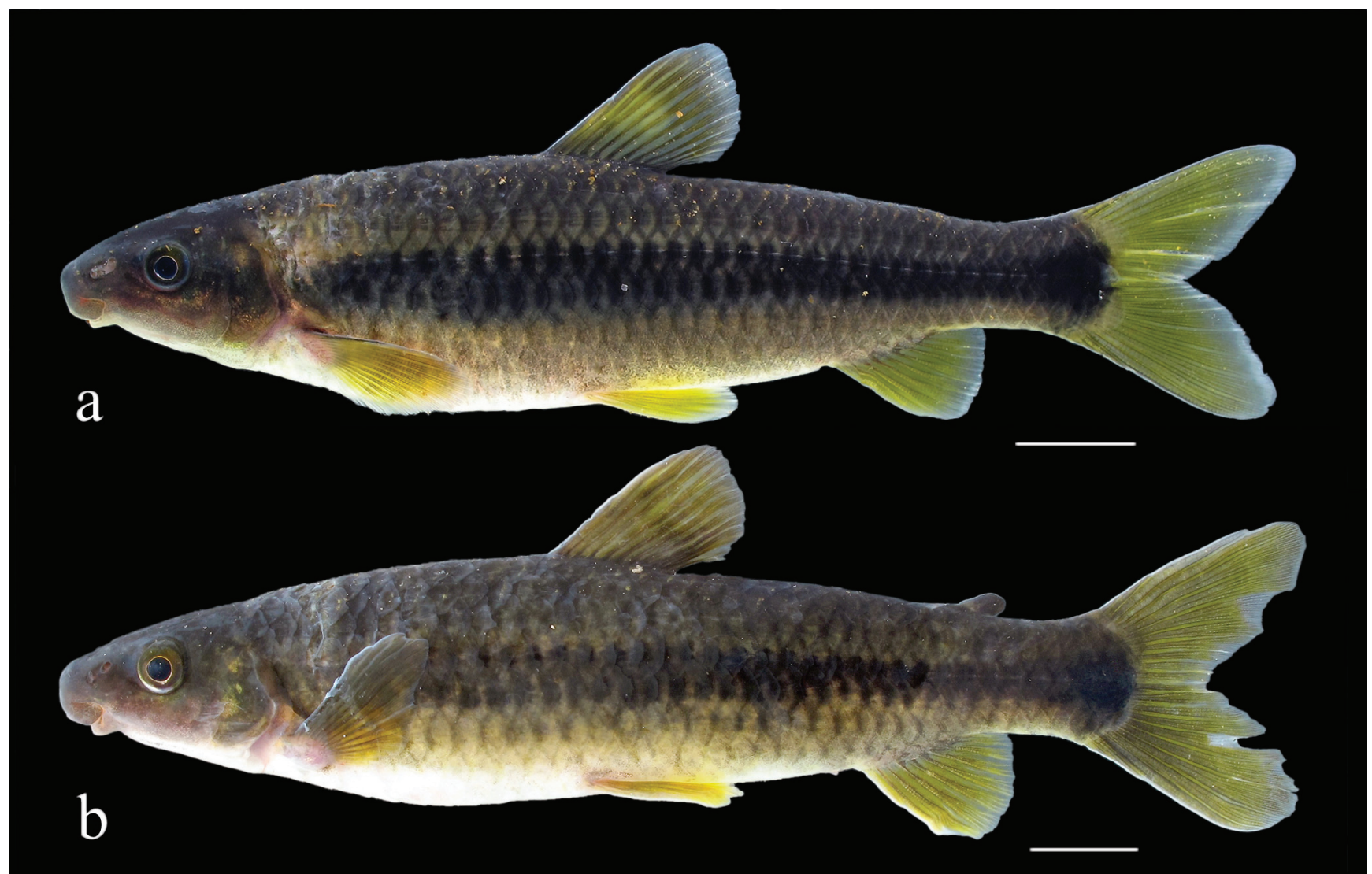

Fig. 7. Leporinus melanopleurodes: (a) paratype, MZUSP 111242, $87.4 \mathrm{~mm}$ SL, rio das Almas, (b) paratype, MZUSP 111227, $99.2 \mathrm{~mm}$ SL, rio Jiquiriçá [specimen lacking adipose fin], photographed live. Scale bars $=10 \mathrm{~mm}$.

2009, F. T. F. Aleluia. MCP 36978, 2, 99.3-173.8 mm SL, Aureliano Leal, rio Gongogi, tributary of rio de Contas, 14¹7'09'S 39॰12'09'W, 11 Oct 2004, J. F. Pezzi da Silva. MCP 43664, 1, 126.5 mm SL; MZUSP 111257, 4, 74.4-157.0 mm SL, collected with holotype. MZUSP 100989, 1, $73.3 \mathrm{~mm} \mathrm{SL}$, Dário Meira, rio do Ouro, tributary of rio Gongogi, between Dário Meira and Gongogi, 14²3'2"S 3942'2”W, 10 Jul 2008, Consultoria Mineraduto Caetité-Ilhéus. MZUSP 102526, 1, 44.3 $\mathrm{mm}$ SL, Caetanos, rio Gavião, at confluence with rio Gado Bravo, $14^{\circ} 15^{\prime} 01^{\prime}$ 'S $41^{\circ} 03^{\prime} 01$ 'W, 8 Feb 2009, P. Hollanda Carvalho, S. M. Q. Lima \& D. F. Almeida. MZUSP 102552, 1, 28.8 mm SL, Dário Meira, rio Gongogi, downstream of confluence with rio Novo, 14²6’06"S 3949'54"W, 11 Feb 2009, P. Hollanda Carvalho, S. M. Q. Lima \& D. F. Almeida. MZUSP 102583, 1, $27.4 \mathrm{~mm}$ SL, Gongogi, rio do Ouro, between Dário Meira and Gongogi, 14²3'2”S 3942'11'W, 11 Feb 2009, P. Hollanda Carvalho, S. M. Q. Lima \& D. F. Almeida. MZUSP 102596, 1, $124.8 \mathrm{~mm}$ SL, Gongogi, rio Pontal do Sul, tributary of rio Gongogi, 14²1'3"S 39॰31'46”'W, 11 Feb 2009, P. Hollanda Carvalho, S. M. Q. Lima \& D. F. Almeida. MZUSP 109762, 1, 38.6 mm SL, Piatã, rio de Contas, on road between Cabralia and Piatã, $13^{\circ} 6$ '33"S 41' 46'53"W, 8 Jul 2011, A. M. Zanata, J. L. Birindelli, P. Camelier, R. Burger and B. Sardeiro. MZUSP 111261, 1 SK, 177.0 mm SL, Ipiaú, rio de Contas, approximately 14ㅇ' 'S 3944'W, 14 Aug 2012, J. L. Birindelli, F. C. Dagosta \& M. V. Loeb. UNT 9292, 1, 98.2 mm SL, Umburana, rio Brumado, at bridge between Umburana and Cristalândia, ca. $14^{\circ} 10^{\prime} \mathrm{S}$ 4136'W, 17 Jan 2009, A. Akama \& A. B. Soares.

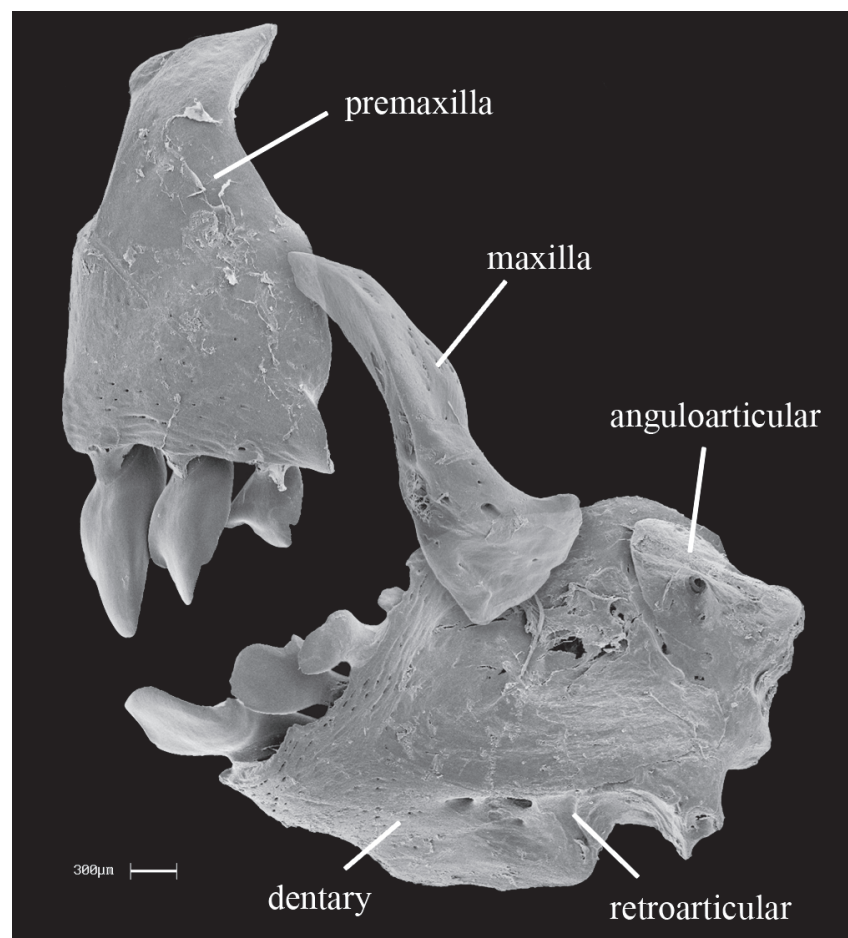

Fig. 8. Scanning electron image of the upper and lower jaws of Leporinus melanopleurodes, in lateral view, MZUSP 109769, $89.5 \mathrm{~mm}$ SL. 


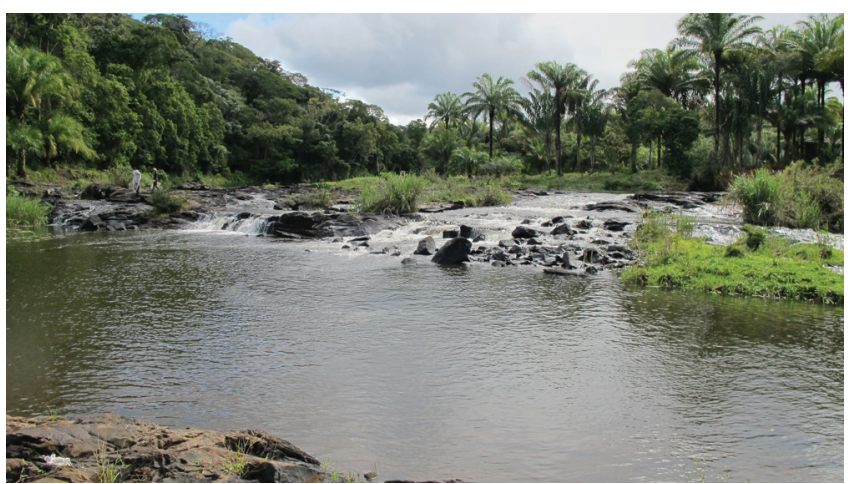

Fig. 9. Rio das Almas, Bahia, Nilo Peçanha, at 1336’27.8”S $39^{\circ} 8^{\prime} 38.8^{\prime \prime} \mathrm{W}$, type locality of Leporinus melanopleurodes.

Diagnosis. Leporinus brinco is distinguished from all congeners by having a bright red blotch immediately dorsal to pectoral-fin origin in live specimens ( $v s$. absent), three dark blotches along the lateral line that distinctly increase in size posteriorly ( $v s$. three dark blotches absent or, when present, decreasing in size posteriorly, as in Leporinus friderici (Bloch), and dark longitudinal lines between the scale rows on the side of body ( $v s$. longitudinal lines absent in all congeners except L. cylindriformis Borodin, L. macrocephalus Garavello $\&$ Britski, and L. nattereri Steindachner.

Description. Morphometric data in Table 3. Moderate in size, relative to congeners. Largest examined specimen $187.2 \mathrm{~mm}$ SL. Head and body elongate and moderately compressed. Dorsal profile of head and body straight from snout tip to tip of supraoccipital, and gently convex from latter point to dorsalfin insertion, somewhat straight along dorsal-fin base, straight from terminus of dorsal-fin base to adipose-fin origin, and distinctly concave from adipose-fin origin to base of anteriormost procurrent ray of caudal fin. Ventral profile straight to slightly concave from lower jaw to vertical through posterior margin of opercle, gently convex from latter point to pelvic-fin origin, straight or slightly convex from pelvic-fin origin to anal-fin origin, somewhat straight along anal-fin base, and concave from terminus of anal-fin base to base of anteriormost procurrent ray of caudal fin. Greatest body depth at dorsal-fin origin.

Mouth subinferior, and horizontally aligned with ventral margin of infraorbitals, in specimens around $50 \mathrm{~mm}$ SL or longer (Fig. 10a-b). Mouth subterminal in specimens around $40 \mathrm{~mm}$ SL (Fig. 10c) and slightly upturned in specimens around $25 \mathrm{~mm}$ SL (Fig. 10d). Snout round, anteriorly blunt. Premaxilla with three incisiform teeth gradually decreasing in size from the symphyseal tooth; symphyseal tooth bicuspid with median cusp moderately smaller than lateral cusp in all examined specimens. Dentary with three incisiform teeth also gradually decreasing in size posterolaterally (Fig. 12).

Scales cycloid, with 3 (1), 4 (1), or 5 (1) radii. Lateral line complete, extending from supracleithrum to base of median caudal-fin rays, with $36(8), 37 *(20)$, or 38 (1) perforated scales. Longitudinal scale rows between dorsal-fin origin and lateral line 4 (29). Longitudinal scale rows between lateral line and pelvic-fin origin 4 (29). Longitudinal scale rows around caudal peduncle 12 (29). Predorsal scales 9 (1), 10 (17), or 11*(2).

Dorsal-fin rays ii, $9(1)$, ii, $10 *(18)$. Dorsal-fin origin slightly anterior to midpoint of standard length and to vertical through pelvic-fin origin; distal margin of dorsal fin straight or slightly convex. Adipose fin small, teardrop-shaped with origin approximately at vertical through middle of anal-fin base. Adipose fin lacking in a single specimen. Pectoral-fin rays i,14 (1), i,15 (2), i,16* (15) or i,17 (1). Tip of pectoral fin extending slightly beyond midpoint between origins of pectoral and pelvic fins; distal margin of pectoral fin rounded. Pelvic-fin rays i,8 (19). Distal margin of pelvic fin slightly convex. Anal-fin rays ii,8 (19). Anal-fin origin approximately at vertical through posterior margin of fourth scale anterior to adipose-fin origin. Tip of adpressed fin almost reaching base of caudal-fin rays; distal margin of anal fin slightly concave. Principal caudal-fin rays i,8,9,i (19). Caudal fin forked, lobes rounded, upper lobe slightly longer than lower lobe. Vertebrae 35 (1) or 36 (2).

Table 2. Morphometric data for Leporinus melanopleurodes. $\mathrm{n}=$ number of specimens; $\mathrm{SD}=\mathrm{Standard}$ Deviation.

\begin{tabular}{lcccc}
\hline & $\mathrm{n}$ & Holotype & Mean & Range \\
\hline Standard Length $(\mathrm{mm})$ & 20 & 99.4 & 98.34 & $79.80-128.70$ \\
& Percentages of Standard Length & & \\
Predorsal distance & 20 & 46.60 & 47.24 & $46.14-48.89$ \\
Dorsal-fin origin to adipose-fin origin & 20 & 83.27 & 83.09 & $81.21-84.68$ \\
Prepelvic distance & 20 & 47.11 & 48.11 & $45.94-51.69$ \\
Body depth & 20 & 24.15 & 23.08 & $21.75-24.50$ \\
Caudal peduncle length & 20 & 16.05 & 15.96 & $14.91-17.17$ \\
Caudal peduncle depth & 20 & 10.39 & 10.49 & $9.61-11.15$ \\
Anal-fin lobe length & 20 & 13.94 & 13.84 & $12.19-15.14$ \\
Head length & 20 & 21.87 & 22.57 & $21.29-24.89$ \\
& Percentages of Head Length & 0.54 & 0.46 \\
Preopercle length & 20 & 76.54 & 77.28 & $75.39-81.44$ \\
Snout length & 20 & 45.86 & 43.59 & $40.88-45.86$ \\
Head depth & 20 & 72.08 & 71.98 & $65.12-77.90$ \\
Eye diameter & 20 & 19.92 & 20.58 & $18.12-23.76$ \\
Bony interorbital & 20 & 38.78 & 39.37 & $35.23-42.27$ \\
\hline
\end{tabular}


Color in alcohol. Ground coloration of head and body tan; weakly countershaded. Body with two or three round dark midlateral blotches, first usually absent but sometimes present as small blotch (smaller than individual scale) along vertical through base of third or second posteriormost rays of dorsal fin; second blotch small (encompassing three scale rows of length and one of depth), at vertical through anal-fin origin; third blotch large (encompassing approximately five scale rows of length and two of depth) on end on caudal peduncle. Body with dark longitudinal lines between scale rows. Ventral

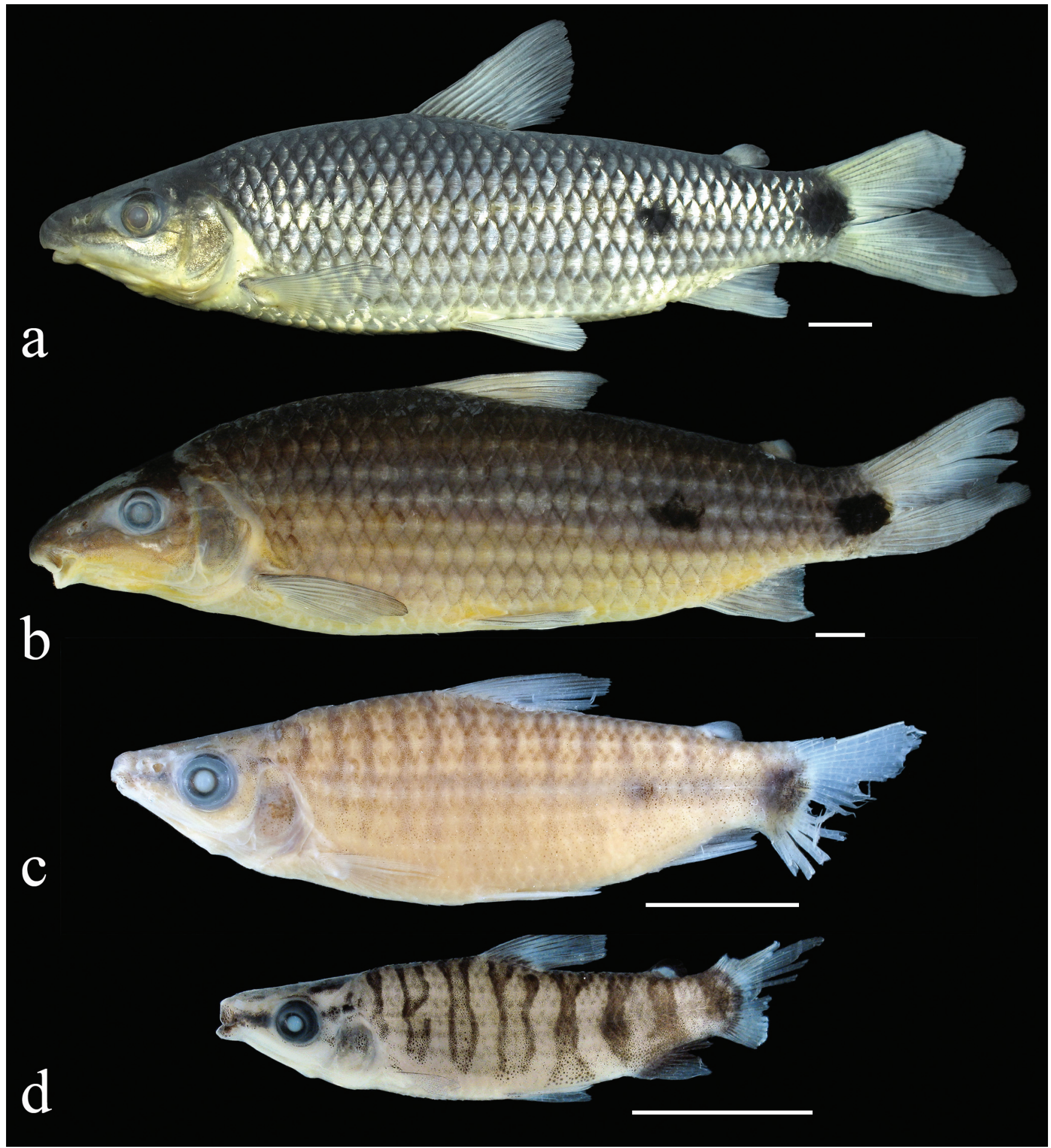

Fig. 10. Leporinus brinco: (a) holotype, MZUSP 105166, 128.5, rio Gongogi, tributary of rio de Contas; (b) paratype, UFBA 4843, 174.9 mm SL, rio de Contas; (c) paratype, MZUSP 102526, $44.3 \mathrm{~mm}$ SL, rio Gavião, tributary of rio de Contas; (d) paratype, MZUSP 102552, $28.8 \mathrm{~mm}$ SL, rio Gongogi, tributary of rio de Contas. Scale bars $=10 \mathrm{~mm}$. 


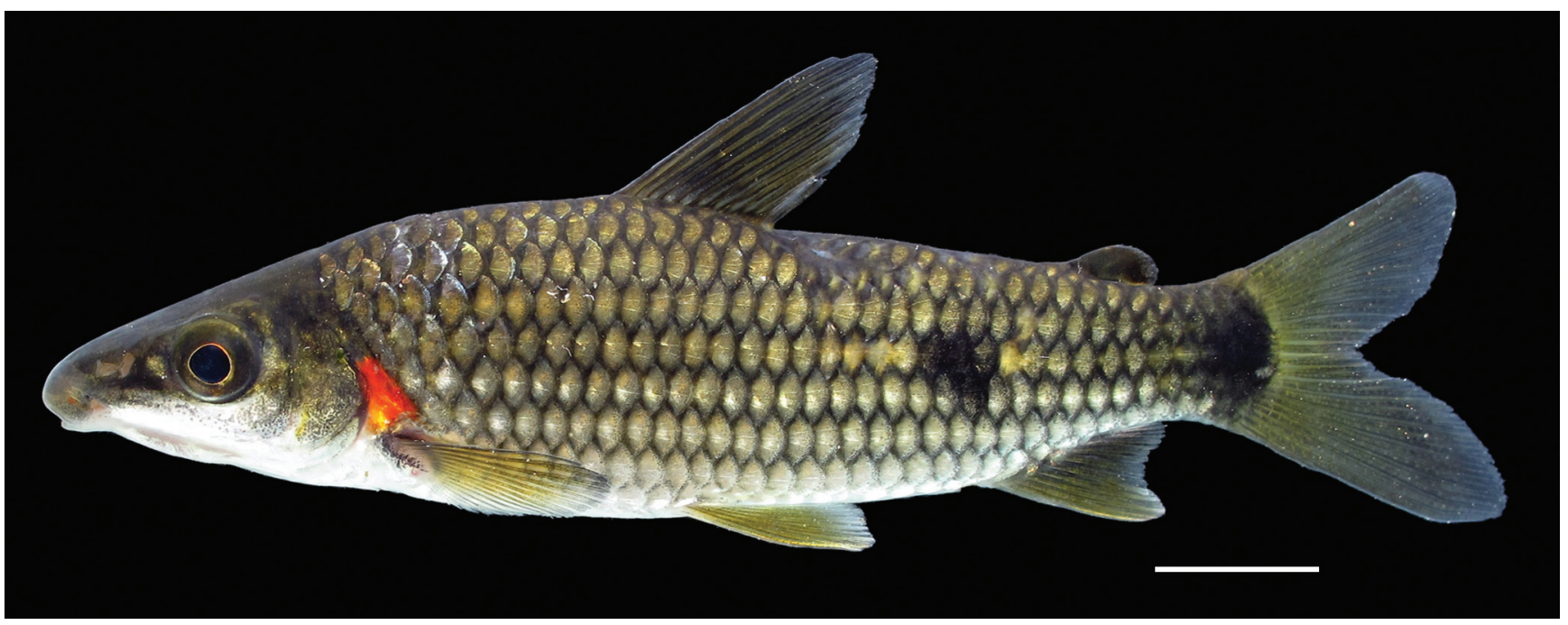

Fig. 11. Leporinus brinco, paratype, MZUSP 111257, $74.4 \mathrm{~mm}$ SL, rio Gongogi, tributary of rio de Contas, photographed live. Scale bar $=10 \mathrm{~mm}$.

surfaces of head and belly pale to cream. All fins hyaline overall. Specimens up to $25 \mathrm{~mm}$ SL with dark stripe from lower jaw to opercle, with eight dark bars on body, and dark spot on median caudal-fin rays (Fig. 10d). Specimens of approximately $40 \mathrm{~mm}$ SL with 14 or 15 dark bars on dorsum and lateral surface of body and two or three midlateral blotches, as described above.

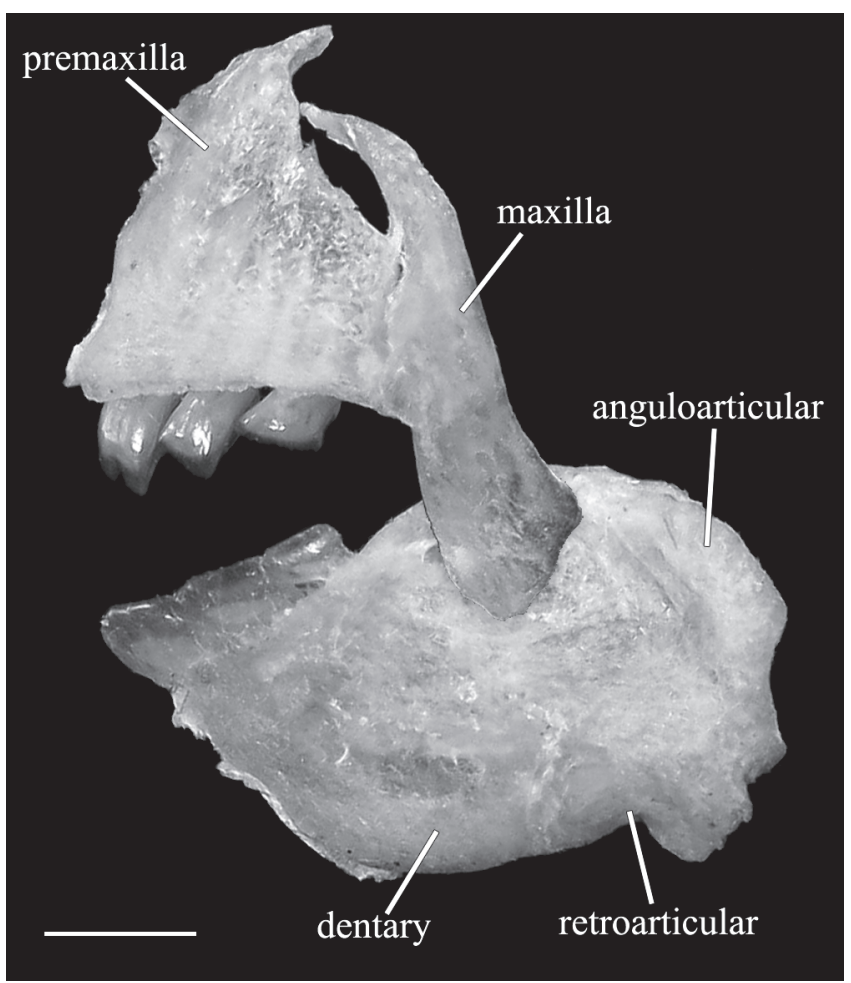

Fig. 12. Image of the upper and lower jaws, in lateral view, of Leporinus brinco, in lateral view, MZUSP 110617, paratype, $139.0 \mathrm{mmSL}$.
Color in life. Life coloration similar to that of preserved specimens, except head and body greenish silver, bright red blotch immediately dorsal to pectoral-fin origin, and small dusky red pigmentation on dorsal and distalmost portions of upper lip (Fig. 11).

Distribution. Leporinus brinco is known from the rio de Contas and its tributaries (Fig. 13), a medium size coastal river in the states of Minas Gerais and Bahia, Brazil (Fig. 4).

Etymology. The specific name brinco is in reference to the vernacular name of the species, "piau-brinco", which means a species of Leporinus ("piau") with an earring ("brinco" in Portuguese) in allusion to the red blotch behind the head, immediately dorsal to pectoral-fin origin. A noun in apposition.

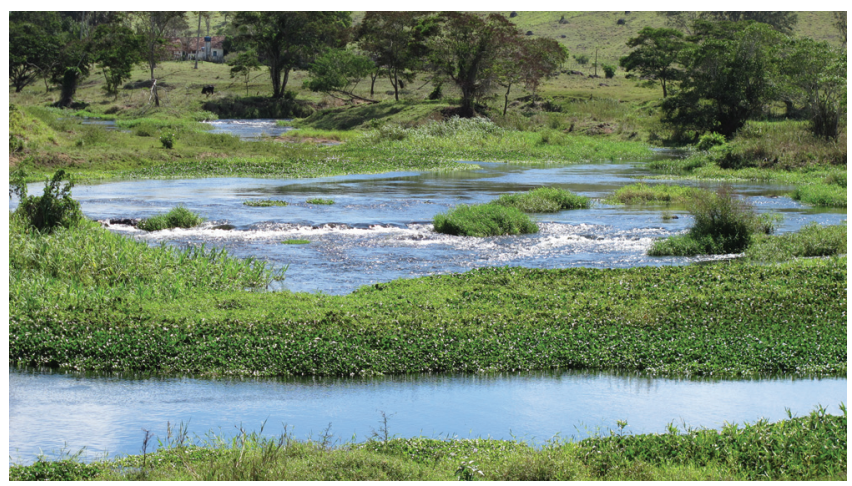

Fig. 13. Rio Gongogi, tributary of rio de Contas, Bahia, Itajibáat $14^{\circ} 21^{\prime} 16.5^{\prime} \mathrm{S} 39^{\circ} 46^{\prime} 23.9^{\prime \prime} \mathrm{W}$, type locality of Leporinus brinco. 
Table 3. Morphometric data for Leporinus brinco. $\mathrm{n}=$ number of specimens; $\mathrm{SD}=$ Standard Deviation.

\begin{tabular}{|c|c|c|c|c|c|}
\hline & $\mathrm{n}$ & Holotype & Mean & Range & SD \\
\hline Standard Length (mm) & 27 & 128.5 & 126.12 & $26.90-187.20$ & \\
\hline \multicolumn{6}{|c|}{ Percentages of Standard Length } \\
\hline Predorsal distance & 20 & 48.83 & 49.65 & $48.23-51.57$ & 1.00 \\
\hline Dorsal-fin origin to adipose-fin origin & 20 & 86.25 & 85.79 & $83.90-87.41$ & 0.97 \\
\hline Prepelvic distance & 20 & 53.39 & 51.88 & 49.34-53.89 & 1.17 \\
\hline Body depth & 20 & 26.55 & 27.81 & $25.26-29.45$ & 1.18 \\
\hline Caudal peduncle length & 20 & 10.97 & 12.45 & $10.86-14.00$ & 1.02 \\
\hline Caudal peduncle depth & 20 & 10.97 & 10.82 & $9.96-11.46$ & 0.41 \\
\hline Anal-fin lobe length & 17 & 14.61 & 14.32 & $12.41-15.30$ & 0.75 \\
\hline Head length & 20 & 26.49 & 27.09 & $25.75-29.47$ & 0.99 \\
\hline \multicolumn{6}{|c|}{ Percentages of Head Length } \\
\hline Preopercle length & 20 & 76.88 & 78.55 & $76.59-81.02$ & 1.32 \\
\hline Snout length & 20 & 42.13 & 44.06 & $41.20-46.75$ & 1.58 \\
\hline Head depth & 20 & 70.48 & 68.86 & $62.15-76.13$ & 3.83 \\
\hline Eye diameter & 20 & 22.91 & 21.51 & $18.18-25.75$ & 2.15 \\
\hline Bony interorbital & 20 & 32.02 & 34.16 & $31.02-37.04$ & 1.62 \\
\hline
\end{tabular}

\section{Discussion}

The conspicuous red blotch immediately dorsal to pectoral-fin origin present in Leporinus brinco is a unique feature among anostomids. The only anostomid species with somewhat similar pigmentation is Leporinus melanostictus Norman, which has a blotch immediately dorsal to the pectoralfin origin that is dark in preserved (Planquette et al., 1996; Sidlauskas \& Vari, 2012) and live specimens collected during day, but becomes red during the night (Fig. 14). Given many other differences between these taxa (e.g., mouth position, body shape), it seems unlikely that Leporinus melanostictus and $L$. brinco are closely related.

Leporinus brinco is similar to L. elongatus Valenciennes in having 36 to 38 scales in lateral line (L. elongatus with 36 or 37), 12 scale rows around caudal peduncle, four scale rows above and below the lateral line, three teeth on the premaxilla and dentary, and long snout with subterminal mouth (see Britski et al. (2012) for diagnostic features of L. elongatus). Leporinus brinco is, on the other hand, also similar to $L$. conirostris Steindachner by having three teeth on both the premaxilla and dentary, long snout with subterminal mouth and anteriormost dark blotch of body completely faded in large specimens. These similarities might suggest that these three species are closely related. Interestingly is the fact that Leporinus elongatus is endemic to rio Jequitinhonha and rio Pardo, two river basins located close to rio de Contas, and $L$. conirostris is distributed in coastal rivers south of rio Jequitinhonha (Fig. 4).

Leporinus melanopleurodes is distinguished from $L$. melanopleura based on differences in mouth position and coloration (see Diagnosis). Although subtle, the difference in mouth position is related to the development of several bones of the anterior portion of head. In L. melanopleurodes the anterior margin of the antorbital is aligned with the anteriormost pore of first infraorbital (character 2, state 0 of Sidlauskas \& Vari, 2008), the mesethmoid has a well-developed lateral process on its anterior portion (character 16, state 1 of
Sidlauskas \& Vari, 2008), and the dorsalmost portion of the ectopterygoid is posterior to its ventralmost portion (character 72, state 1 of Sidlauskas \& Vari, 2008). Leporinus melanopleura, on the other hand, has the anterior margin of

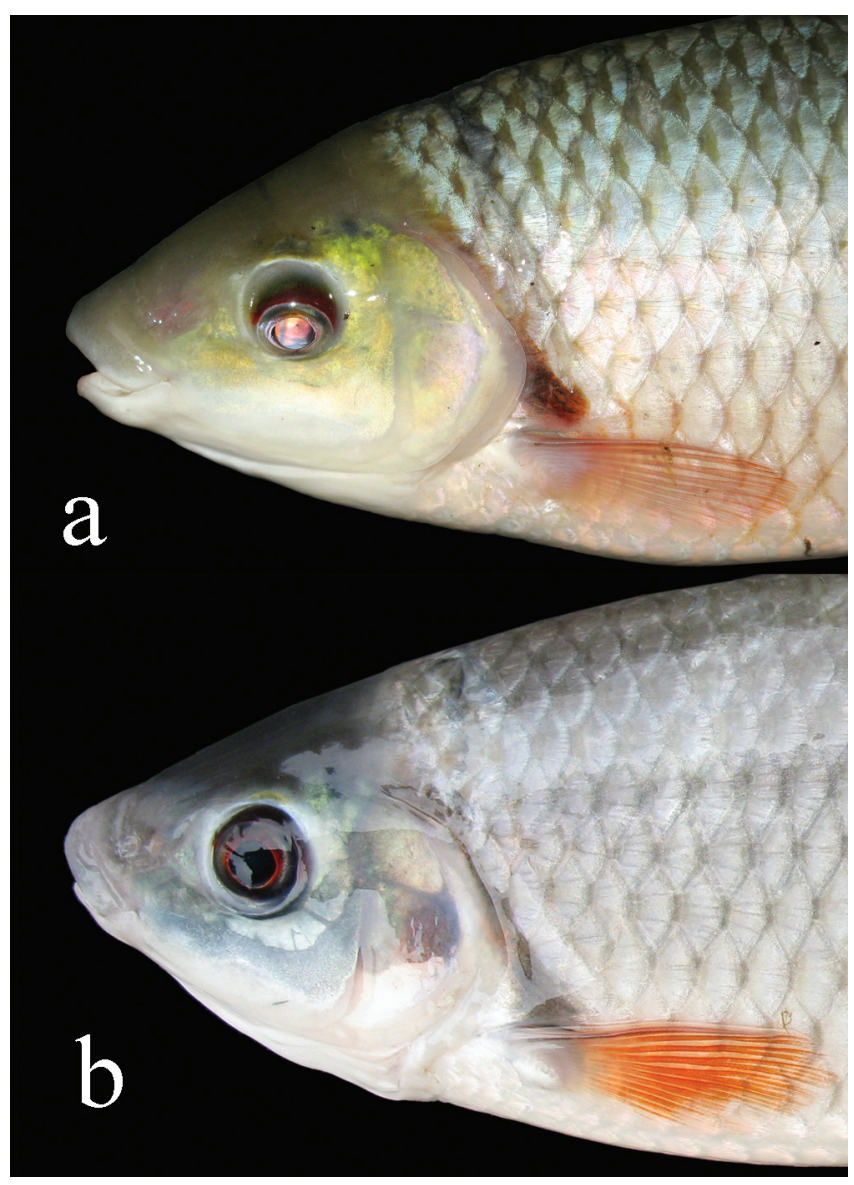

Fig. 14. Leporinus melanostictus, (a) MZUSP 103242, 225.0 $\mathrm{mm}$ SL, rio Jari; (b) MZUSP 103242, $221.0 \mathrm{~mm}$ SL, rio Iratapuru, tributary of rio Jari. 
the antorbital anterior to the anteriormost pore of the first infraorbital (character 2, state 1 of Sidlauskas \& Vari, 2008), the process on the anterior portion of the mesethmoid absent (character 16, state 0 of Sidlauskas \& Vari, 2008), and the dorsalmost portion of ectopterygoid anterior to its ventralmost portion (character 72, state 0 of Sidlauskas \& Vari, 2008). These characters could indicate that the two species belong to distinct lineages within anostomid fishes. Nevertheless, Leporinus melanopleura and L. melanopleurodes are indistinguishable in all meristic and morphometric data (see description and Tables 1 and 2) and they share a unique color pattern, which consists of a single dark stripe encompassing one or two scale rows of depth and centered below lateral line. In all other congeners with a dark stripe (Leporinus amae, L. arcus, L. amblyrhynchus, L. bistriatus, L. britskii, L. despaxi Puyo, L. sexstriatus, L. striatus, L. taeniatus, $L$. taeniofasciatus, L. unitaeniatus, and L. vanzoi), the latter is centered on the lateral-line scale row. In addition, both species have the fourth and fifth infraorbitals fused (character 9, state 1 of Sidlauskas \& Vari, 2008). This last character is present in some other species with subinferior mouth (Birindelli \& Britski, 2009), and shows some intra-specific variation (Sidlauskas \& Vari, 2008: 86), but it is absent in species with inferior mouth (see Sidlauskas \& Vari, 2008). Therefore, it is also possible that Leporinus melanopleura and L. melanopleurodes are sister taxa. Interestingly is that both species are restricted to small coastal rivers in Bahia, Brazil, north of rio Pardo and south of rio Paraguaçu. A comprehensive phylogenetic analysis that includes most species of Leporinus and Hypomasticus Borodin, in addition to the new species described here, is necessary for understanding the phylogenetic relationships among basal anostomids, and therefore an accurate hypothesis of phylogenetic position of Leporinus brinco, L. melanopleura and L. melanopleurodes. This study is beyond the present contribution, as it will be tackled in a separate publication.

Comparative material. Leporinus melanostictus. Brazil. Amapá, MZUSP 103242, 4, 77.0-225.0 mm SL, Laranjal do Jari, rio Iratapucu, tributary of rio Jari, 0`33'59’S 52॰34'43”W. Leporinus taeniatus. Brazil. Bahia. MZUSP 83840, 1, 103.0 mm SL, Formosa do Rio Preto, rio São Francisco basin, rio Preto, 11²'59'S 4511'31'W. MZUSP 92043, 5, 34.1-42.7 mm SL, Queimadas, rio Itapicuru basin, rio Jacurici, 1054'46”S 39³7'25’'W. Ceará. MZUSP 37583, 3, 79.0$106.9 \mathrm{~mm}$ SL, Aiuaba, riacho do Umbuziero. Minas Gerais. BMNH 1861.5.16.14, $102.6 \mathrm{~mm} \mathrm{SL}$, paralectotype of Leporinus melanopleura Günther, 1864, rio Cipó, tributary of rio das Velhas, rio São Francisco basin. MZUSP 47459, 3, 65.0-96.5 mm SL, Montes Claros, rio Verde, tributary of rio São Francisco. MZUSP 47464, 1, 139.0 mm SL, Montes Claros, rio São Francisco basin, rio Verde, between Francisco Sá and Montes Claros, $16^{\circ} 44^{\prime}$ S 4351'W. MZUSP 73691, 1, 130.2 mm SL; MZUSP 73777, 1, 136.0 mm SL, Augusto de Lima, rio São Francisco basin, rio Curimataí, at Fazenda Vitória, $18^{\circ} 5^{\prime} 43^{\prime}$ 'S 44 $16^{\prime}$ '15'W. NMW 68040, 2, 77.5 and 125.8 mm SL; NMW 68041, 1, 142.5 mm SL; NMW 68042, 1, 132.6 mm SL; NMW 68182, 1, $154.1 \mathrm{~mm}$ SL; NMW 68197, 2, 98.3 and $120.8 \mathrm{~mm}$ SL; NMW 70647, 2, 79.3 and 116.4 mm SL, syntypes of Leporinus taeniatus Lütken, 1875, rio das Velhas, tributary of rio São Francisco.

\section{Acknowledgments}

For critical review of the manuscript we thank Brian Sidlauskas, Naércio Menezes and two anonymous reviewers. We are grateful to Fabrício T. F. Aleluia, Alberto Akama, Pedro Hollanda Carvalho and Angela M. Zanata for collecting and sending us specimens. We thank Rafael Burger and Pedro Hollanda Carvalho for providing pictures of specimens. For loan and assistances during collection visits we thank Mark Sabaj Pérez and John Lundberg (ANSP), James Maclaine, Oliver Crimmen, Patrick Campbell and RalfBritz(BMNH), Zilda Margarete de Lucena (MCP), Alberto Akama (UNT), Helmut Wellendorf and Christian Pollman (NMW) and Richard Vari (USNM). For assistance with scanning electron microscopy images we thank Lara Maria Guimarães (MZUSP). For assistance during field trips we thank Angela Zanata, Bianca Moraes, Fernando Dagosta, Marina Loeb, Priscila Camelier and Rafael Burger. Authors were financially supported by FAPESP (grant 10/51250-9 - JLOB) and CNPq (HAB, JCG).

\section{Literature Cited}

Bemis, W. F., E. J. Hilton, B. Brown, R. Arrindell, A. M. Richmond, C. D. Little, L. Grande, P. L. Forey \& G. J. Nelson. 2004. Methods for preparing dry, partially articulated skeletons of Osteichthyans, with notes on making ridewood dissections of the cranial skeleton. Copeia, 2004: 603-609.

Birindelli, J. L. O. \& H. A. Britski. 2009. New species of the genus Leporinus Agassiz (Characiformes: Anostomidae) from the rio Curuá, rio Xingu basin, Serra do Cachimbo, Brazil, with comments on Leporinus reticulatus. Neotropical Ichthyology, 7: 1-10.

Britski, H. A., J. L. O. Birindelli \& J. C. Garavello. 2011. Synaptolaemus latofasciatus, a new combination for Leporinus latofasciatus Steindachner, 1910 and its junior synonym Synaptolaemus cingulatus Myers and Fernández-Yépez, 1950 (Characiformes: Anostomidae). Zootaxa, 3018: 59-65.

Britski, H. A., J. L. O. Birindelli \& J. C. Garavello. 2012. A new species of Leporinus Agassiz, 1829 from the upper Rio Paraná basin (Characiformes, Anostomidae) with redescription of $L$. elongatus Valenciennes, 1850 and L. obtusidens (Valenciennes, 1837). Papéis Avulsos de Zoologia, 52: 441-475.

Britski, H. A. \& J. C. Garavello. 1978. Sobre Leporinus octofasciatus Steindachner da bacia do Paraná (Pisces, Anostomidae). Papéis Avulsos de Zoologia, 31: 237-250.

Britski, H. A. \& J. C. Garavello. 2007. Família Anostomidae. Pp. 23-27. In: Buckup, P. A., N. A. Menezes \& M. S. A. Ghazzi (Eds.). Catálogo das espécies de peixes de água doce do Brasil. Rio de Janeiro, Museu Nacional, 195p.

Britski, H. A., Y. Sato \& A. B. S. Rosa. 1988. Manual de identificação de peixes da Região de Três Marias. Brasília, Câmara dos Deputados/CODEVASF, 143p.

Eigenmann, C. H. 1910. Catalogue of the fresh-water fishes of tropical and south temperate America. Pp. 375-511, In: Reports of the Princeton University expeditions to Patagonia 1896-1899, Zoology, vol. 3. Princeton University.

Eigenmann, C. H. \& R. S. Eigenmann. 1891. A catalogue of the fresh-water fishes of South America. Proceedings of the United States National Museum, 14: 1-81. 
Eschmeyer, W. N. 2012. Catalog of Fishes. California Academy of Sciences (http://research.calacademy.org/research/ichthyology/ catalog/fishcatmain.asp). Electronic version accessed 1 Sep 2012.

Feitosa, F. S., G. M. Santos \& J. L. O. Birindelli. 2011. Leporinus britskii: a new species form the Tapajós and Jari drainages, Brazil (Characiformes: Anostomidae). Zootaxa, 3120: 55-62.

Fowler, H. W. 1941. A collection of fresh-water fishes obtained in eastern Brazil by Dr. Rodolpho von Ihering. Proceedings of the Academy of Natural Sciences of Philadelphia, 93: 123-199.

Fowler, H. W. 1950. Os peixes de água doce do Brasil. I. Arquivos de Zoologia do Estado de São Paulo, 6: 1-625.

Gama, C. S. 2011. A ictiofauna do Parque Nacional Montanhas do Tumucumaque obtida em cinco inventários rápidos. Pp. 71-77. In: E. Bernard (Ed.) Inventários Biológicos Rápidos no Parque Nacional Montanhas do Tumucumaque, Amapá, Brasil. RAP Bulletin of Biological Assessment 48. Arlington, Conservation International. $145 \mathrm{p}$.

Garavello, J. C. 1979. Revisão taxonômica do gênero Leporinus Spix, 1829 (Ostariophysi, Anostomidae). Unpublished Ph.D. Dissertation, Instituto de Biociências da Universidade de São Paulo, 451p.

Garavello, J. C. \& H. A. Britski. 2003. Family Anostomidae. Pp. 71-84. In: Reis, R. E., S. Kullander \& C. F. Ferraris Jr. (Eds.). Check List of the Freshwater Fishes of South and Central America. Porto Alegre, Edipucrs, 742p.

Géry, J. 1960. Contributions to the study of the characoid fishes, No. 9. Some South-American characoid fishes in the Senckenberg Museum, with the description of a new Leporinus. Senckenbergiana Biologica, 41: 273-288.

Géry, J. 1977. Characoids of the world. Neptune City, TFH Publications, 672p.

Günther, A. 1864. Catalogue of the fishes in the British Museum, vol. 5. - Catalogue of the Physostomi, containing the families Siluridae, Characinidae, Haplochitonidae, Sternoptychidae, Scopelidae, Stomiatidae in the collection of the British Museum. Trustees, London, 455p.

Lasso, C. A., D. Lew, D. Taphorn, C. DoNascimento, O. LassoAlcalá, F. Provenzano \& A. Machado-Allison. 2004. Biodiversidad ictiológica continental de Venezuela. Parte I. Lista de especies y distribución por cuencas. Memorias de la Fundación La Salle de Ciencias Naturales, 159-160: 5-95.

Lasso, C. A., J. S. Usma Oviedo, F. Villa, M. T. Sierra-Quintero, A. Ortega-Lara, L. M. Mesa, M. A. Patiño, O. M. Lasso-Alcalá, M. A. Morales-Betancourt, K. González-Oropesa, M. P. Quiceno, A. Ferrer \& C. F. Suárez. 2009. Peces de la Estrella Fluvial Inírida: ríos Guaviare, Inírida, Atabapo y Orinoco (Orinoquia colombiana). Biota Colombiana, 10: 89-122.
Lima, F. C. T. 2001. Revisão taxonômica do gênero Brycon Müller \& Troschel, 1844, dos rios da América do Sul cisandina (Pisces, Ostariophysi, Characiformes, Characidae). Unpublished MSc. Dissertation, Instituto de Biociências da Universidade de São Paulo, São Paulo, 312p.

Maldonado-Ocampo, J. A., M. Lugo, J. D. Bogotá-Gregory, C. Lasso, L. Vásquez, J. S. Usma, D. C. Taphorn \& F. Provenzano. 2008. Peces del río Tomo, cuenca del Orinoco, Colombia. Biota Colombiana, 7: 113-128.

Petrere Jr., M. 1989. River fisheries in Brazil: a review. Regulated Rivers: Research and Management, 4: 1-16.

Planquette, P., P. Keith \& P.-Y. Le Bail. 1996. Atlas des poissons d'eau douce de Guyane, Tome 1. Collection du Patrimoine Naturel, vol. 22. Paris, IEGB - M.N.H.N., INRA, CSP, Ministère de l'Environnement, 429p.

Sampaio, E. V. \& Y. Sato. 2009. Aspectos reprodutivos de Leporinus piau Fowler, 1941 (Osteichthyes, Anostomidae) da bacia do rio São Francisco, submetido à desova induzida. Ciência Animal Brasileira, 10: 157-165.

Sidlauskas, B. L. \& R. P. Vari. 2008. Phylogenetic relationships within the South American fish family Anostomidae (Teleostei, Ostariophysi, Characiformes). Zoological Journal of the Linnean Society, 154: 70-210.

Sidlauskas, B. L. \& R. P. Vari. 2012. Diversity and distribution of anostomoid fishes (Teleostei: Characiformes) throughout the Guianas. Cybium, 36: 71-103.

Steindachner, F. 1876. Ichthyologische Beiträge (V). Sitzungsberichte der Kaiserlichen Akademie der Wissenschaften. Mathematisch-Naturwissenschaftliche Classe, 74: 49-240.

Taylor, W. R. \& G. C. van Dyke. 1985. Revised procedures for staining and clearing small fishes and other vertebrates for bone and cartilage study. Cybium, 9: 107-109.

Teixeira, J. L. A. \& H. C. B. Gurgel. 2005. Ocorrência e distribuição temporal da ictiofauna do açude Riacho da Cruz no Rio Grande do Norte. Revista Ceres, 52: 317-324.

Travassos, L. 1940. Relatório da quarta excursão do Instituto Oswaldo Cruz a zona da Estrada de Ferro Noroeste do Brasil, realisada em Agosto e Setembro de 1940. Memorias do Instituto Oswaldo Cruz, 35: 697-722.

Winterbottom, R. 1980. Systematics, osteology and phylogenetic relationships of fishes of the subfamily Anostominae (Characoidei, Anostomidae). Royal Ontario Museum, Life Sciences Contribution, 123: 1-112.

Submitted May 15, 2012 Accepted September 20, 2012 by Paulo H. F. Lucinda Published March 31, 2013 